\title{
A Critical Literature Review of Impact of Supply Chain Management Practice on Construction Project Performance
}

\author{
Dhruv Gor ${ }^{1}$ and Dr. Jayeshkumar Pitroda ${ }^{2}$ \\ ${ }^{I}$ Student of Final year, M. Tech (Construction Engineering \& Management), B.V.M. Engineering College, \\ Vallabh Vidyanagar, Gujarat, India \\ ${ }^{2}$ Assistant Professor, Civil Engineering Dept., B.V.M. Engineering College, Vallabh Vidyanagar, Gujarat, India \\ *Corresponding Author: Dr. Jayeshkumar Pitroda, Assistant Professor, Civil Engineering Department, \\ B.V.M Engineering College, Vallabh Vidhyanagar, Gujarat, India
}

\begin{abstract}
Construction industry confronts a lot of implicit problems and uncertainties. Construction firms know that it is significant to improve the decision making procedure in supply chain development. However, they do not have knowledge how to increase the decision making in supply chain process in relation to the requirements of the companies. One factor is that a lot of organizations do not have knowledge of factors and performance measure, which can support decisions in this area. To improve the decision making in supply chain process, first it is important to know the factors (Parameters) affecting the decision making in construction supply chain process. Use of supply chain management philosophy in the construction industry has been broadly calibrated in recent years as an efficient and effective management strategy and measure to improve the execution of construction. Supply chain management (SCM) can be recognized as the coordination of distributed decision making of organization on information flow and material flow. Supplier selection is one of the main factors in Supply Chain Management. This paper contains a review on various decisions making in construction supply chain management, generally used methods and factors for supplier selection by other industries.
\end{abstract}

Keywords: Supply Chain Management, Delays, Risk, Simulation Decision Making, Parameter, Performance Measures, Alternatives.

\section{INTRODUCTION}

Construction business is the second largest financial activity in India. Construction industry in India can be separated into primary three market fragments: Real Estate, Industrial and Infrastructure. There is a huge venture stream into the infrastructural improvement in India. Looking at the strong future prospects and universal construction activity in the country, it is necessary to ruminate the strategies to enlarge the productivity in construction activity which seems to lag far behind in comparison to other service and manufacturing industries. Construction companies experienced a decrease in productivity and an increase in costs. Owners of these firms thought that these increase in cost were due to economic and inflation problems. Further research explained that was also attributable to poor management.

In the lack of construction companies' beginning for better quality and higher productivity, the construction business has seen commoditization; where contracts are allowed along the premise of least offer. This thusly causes chop down the net revenues and industry members have been unwilling to making speculations for efficiency improvement. Current firm-particular value decrease doesn't present any reasonable favorable position in the overall marketplace. With the expanding worldwide rivalry, Indian firms need to take all the stakeholders of the building supply chain who impact the efficiency of the work of labor. This is conceivable just through more noteworthy coordination among the different members. Firms request to follow a supply chain approach to deal with worldwide standards. Rising incomes of the construction industry and strong future prospects would urge construction firms to make ventures to achieve higher efficiency.

The issue of deferrals, cost over-runs and quality non-conformance is firmly associated with the Supply Chain Management (SCM) and I consider that applying Supply Chain Management standards, 
Use of various strategies and store network coordination can get a noteworthy increment the profitability in construction tasks.

\section{REVIEW OF LITERATURE}

The following are the previous research review based on Impact of Supply Chain Management Practice on Construction Project Performance.

Kamal M. Al-Subhi Al-Harbi et al. (1999) exhibited the AHP as a decision making method that considers the thought of different measures. AHP permits cooperative choice making. The method can also be carried out on a computer. This method is likewise very helpful in supply chain management.(7)

Ruben Vrijhoef et al. (1999) clarified that SCM can assume significant parts inconstruction. The guideline parts of SCM are secured by the generic SCM approach. The generic body of knowledge deposited in the framework of SCM leads to reformed understanding of the characteristics of supply chain problems in construction, and provide guidance for action. Nevertheless, the practical roles for SCM must be obtained in construction rehearse itself, holding into account the attributes of construction and the particular office. (13)

Baldwin et al. (2000) and Hans Voordijk et al. (2003) recognized those three sorts of particularity which all can be connected in construction: modular-in-production, modular-in-design and modularin-use. Modularity-in-production rationalizes a product into portions and allows shares to be standardized and produced independently before assembly into the final arrangement. Modularity-indesign goes a step onward with an overall engineering work and standard interfaces, the modules can be planned freely, and blended and coordinated to make an entire framework. At the long last, an item is modular-in-itself if buyers themselves can blend and match segments to land at a working entirety. The idea of stage get together is firmly fixing to that of modules and item modularization since it enables the item to be separated to a high degree and therefore meet shifted client prerequisites. (3) (6)

Andrew R. J. Dainty et al. (2001) derived that how the supply chain management practices of huge customer associations can be connected to their construction supply chains all the more successfully. The general acquirement rehearses and coming about connections at four levels of the supply chain are being explored with a scope of real development customers. Best practice as to overseeing connections at each level is being distinguished for their center acquirement operations and created to give a change system that can be connected to their construction obtainment exercises. (2)

Syed Mahmood Ahmed et al. (2002) delivered that supply chain management (SCM) is an awesome open door for the construction industry fundamentally to decrease cost and time, and hence enhance gainfulness. The supply chains in construction could be partitioned into two noteworthy gatherings as materials chain and the development chain, which would isolate the management operations and procurement. (18)

Deepesh Giri Sharma et al. (2003) derived that the real restriction of the examination was that the vast majority of the respondents being extremely faithful to the organization and were hesitant to give reaction. The quantities of respondents should be expanded. Subjective techniques have been utilized which produces summed up comes about. This work might be done for other cement manufacturing companies. (4)

Malik Khalfan et al. (2004) stated that SCM varies from the management of relationships currently practiced within the construction industry in two ways: initially SCM considers management relationships as one of its segments, and furthermore SCM does concentrate on quick exchanging accomplices as well as considers all exchanging accomplices of the supply chain network. (8)

Wee et al. (2009) and Per Erik Eriksson et al. a. (2010) found that how different lean related viewpoints can be executed and how they influence supply chain on-screen characters and their execution in a construction project reference. Additionally investigate on execution markers ought to 
be empowered. Execution estimation is an essential part of both lean generation and lean development. Despite the fact construction supply chain execution estimation is critical it is, in any case, more troublesome than in most assembling ventures. (20) (11)

Stuart Tennant et al. (2010) recommended that regardless of developing scholastic and construction industry intrigue, the theoretical understanding and practice of supply chain management keeps on reflecting ideas and contextual investigations established somewhere else. The acquiring of supply chain management hypothesis and dialect is seemingly an instrumentally determined reaction to resultant natural difficulties. Supply chain management in a construction context is over and again anticipated that would reflect execution levels saw in different enterprises, most remarkably producing. (16)

Mansour N. Jadid et al. (2013) described that geodetic supply chain management in engineering spreads all developments and capacity of materials for work in process recording, and for completed items, from the purpose of cause to the construction site. The advantages of the proposed frameworks are key for the construction industry; they would be successful and improve its efficiency.(9)

Syama Krishnakumaret al. (2014) stated thatsupplier selection for the construction industry is very time consuming and hectic job. There arises a need for suitable supplier selection model which makes the purchasing function smooth. This review aims to generalize the various criteria and methods that can be implemented for developing a supplier selection model in construction industry.

Vijay Kumar Sahu et al. (2014) researched that on the premise to this examination it is done the cement industries shortage of supply chain management, the principle objective of this paper is to advance the supply chain management in cement manufacturing and to give the best answer for supply chain management, including the different properties of item and firm, additionally keep help for to give information to showcase intensity between other cement generation firm. (19)

Elizabeth Ojo et al. (2014) concluded that the major barriers facing Green Supply Chain Management in Lagos, Nigeria are public awareness, absence of learning about natural effects, poor responsibility by top management and absence of lawful requirement by the government, while absence of resources, lack of maintainable practices in the association's vision and mission, lack of market for recyclable materials, lack of data sharing between construction firms and providers and lack of interest were additionally distinguished as boundary. Natural issues have turned out to be more applicable in construction firms; therefore construction industries need to concentrate on vitality and assets for making ecologically stable supply chain. To achieve environmentally sound supply chain in construction, obstructions in GSCM must be deflected. (5)

Prof. Mukesh S. Balwani et al. (2015) explained that value stream mapping is an advanced level viewpoint of the procedure. Mapping is to be finished by following the procedure from start to finish and drawing a visual portrayal of essential data steps, data streams, process streams/postponements and key time metric. VSM is an efficient approach lean SCM to assess the stream of significant worth through the operation. It is a helpful apparatus to recognize deferrals and wastages in the operation and to accomplish streamlining of the procedure. (12)

MullaAneesa.I et al. (2015) addressed supply chains in construction could partitioned into two noteworthy gatherings as materials chain and the construction chain, which would isolate the procurement and management operations. However, the two chains are connected through an SCM database, which is additionally connected with the focal project database. This would guarantee the smooth stream of data inside the diverse chains and results in expanded cooperation inside the supply chain accomplices. (10)

Amade, B. et al. (2016) addressed the most critical limitation to the utilization of SCM in the Nigerian construction industry are; lack of comprehension of SCM idea; vague vital advantages; deficiency of trust inside and outside an association; absence of a typical standard for joint effort; and inability to widen the SC vision past obtainment or item dispersion. (1) 
S Vignesh et al. (2016) derived that by utilizing Analytical Hierarchy Process (AHP), it enhances the decision making process in supply chain management by found out the critical factors and performance measures. In many situations, these evaluations are only based on the intuition and expertise of the decision-makers. Moreover, may using this result, the organization can decreased the dangers related with decision-making in the issue identified with choosing providers and other procurement decision, making it conceivable to dispose of some subjective viewpoints identified with the buy of their materials. (15)

\section{Conclusions}

The following major findings from research paper that identified are described below:

1. There are different types of methods and techniques that help to make proper and identical solution for decision making in supply chain management.

2. There are also Analytical Hierarchy Process (AHP), which helps to improve the decision making process in supply chain management.

3. SCM can assume significant parts in construction. SCM prompts enhanced comprehension of the construction supply chain issues, and provides guidance for action.

4. Supply chain management (SCM) is an extraordinary open door for the construction industry principally to diminish cost and time, and consequently enhance gainfulness.

5. Supply chain management plays major role to convey materials from manufacture to related construction site.

6. Supply chains in development could be isolated into two noteworthy gatherings as materials chain and the construction chain, which would isolate the procurement and management operations.

7. To improve supply chain management in construction, there are also need to make strong connection between all participants which relate to any project. And by that it helps to improve decision making process.

8. The requirement for SCM examines was likewise determined by recent market competitiveness, intensity, which is requesting better outcomes from construction firms.

9. The present status of construction is observationally surveyed from a supply chain viewpoint. The consequence of this examination is uncovered to be good both with past perceptions in construction and in make-to-order supply chains.

10. This review paper promotes a better understanding of practical directions to improve supply chain within the construction environment.

After identifying these factors, an integrated framework for assessing the factors affecting supply chain management in construction was developed, which contained main 7 groups containing different 45 factors. This framework, shown in the figure, shall be used for future research work. The following figure 1, 2 and 3 shows integrated framework for assessing factors affecting SCM.

\section{ACKNOWLEDGEMENT}

The Authors thankfully acknowledge to Dr. C. L. Patel, Chairman, Charutar Vidya Mandal, and Er. V. M. Patel, Hon. Jt. Secretary, CharutarVidya Mandal, Prof. (Dr.) Indrajit Patel, Principal, B.V.M. Engineering College, Dr. L. B. Zala, Head and Professor, Civil Engineering Department, Prof. J. J. Bhavsar, Associate Professor, Civil Engineering Department, B.V.M. Engineering College, Vallabh Vidyanagar, Gujarat, India for their motivations and infrastructural support to carry out this research. 


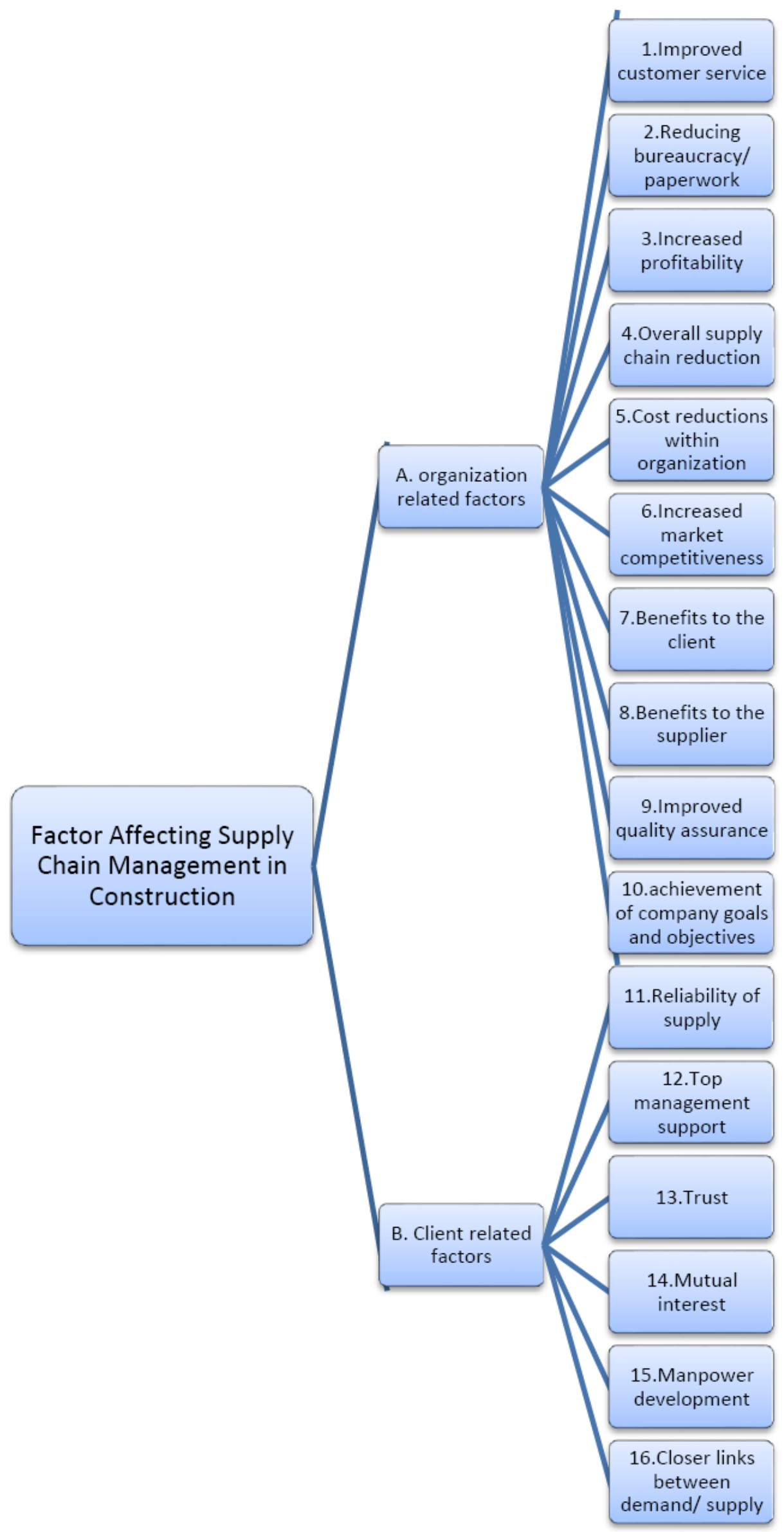

Figure1. Integrated Framework for Assessing Factors Affecting SCM 


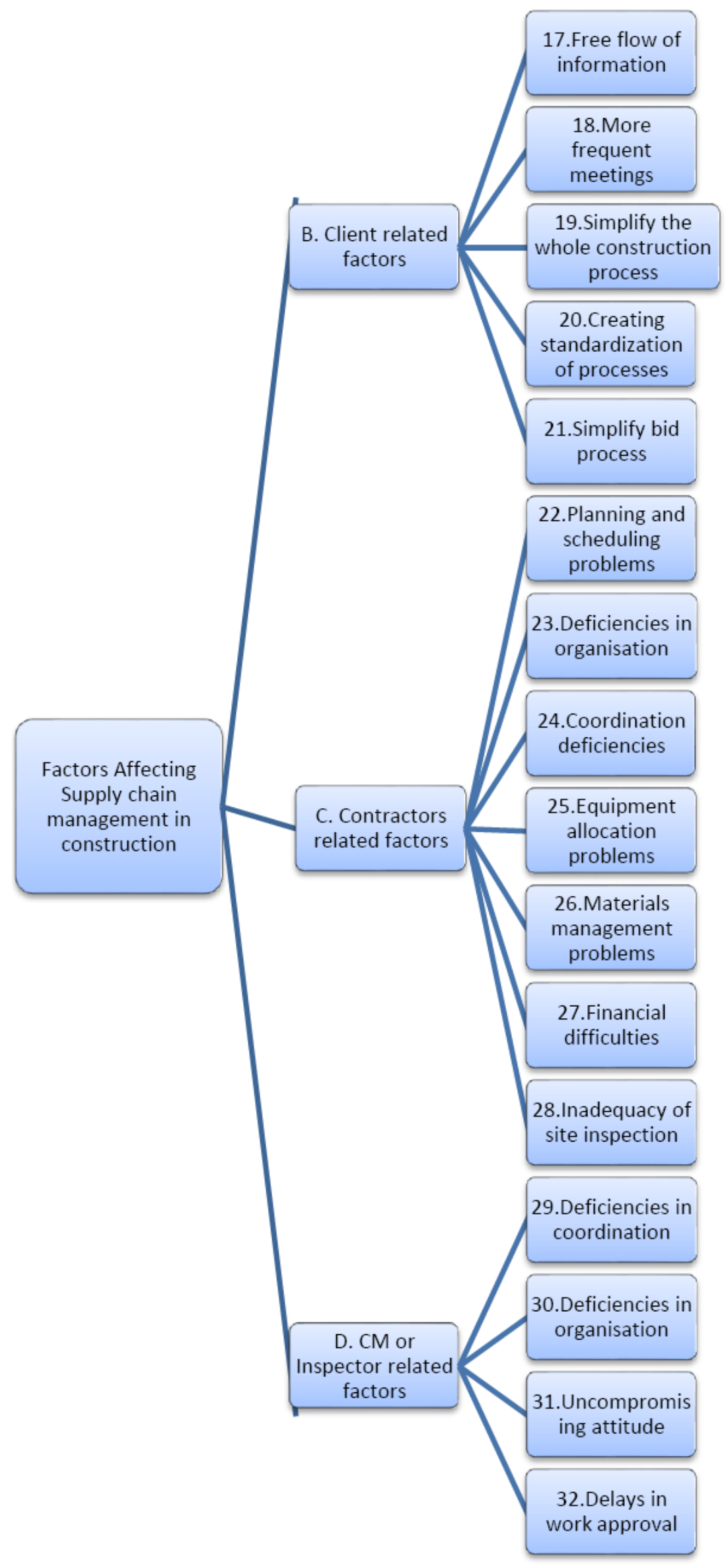

Figure2. Integrated Framework for Assessing Factors Affecting SCM 


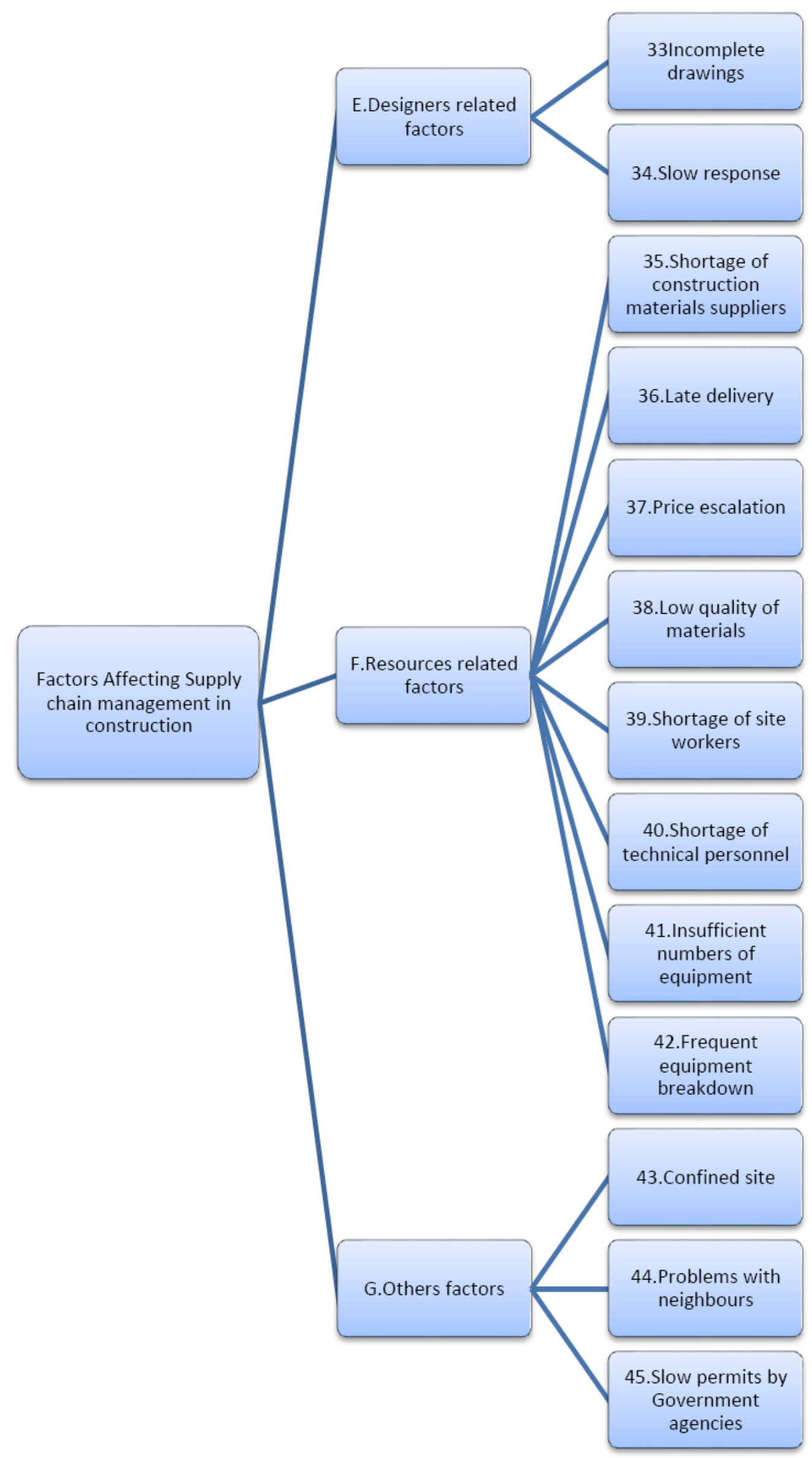

Figure3. Integrated Framework for Assessing Factors Affecting SCM 


\section{REFERENCES}

[1] Amade, B., Akpan, E.O.P., Ubani, E.C.,Amaeshi, U.F. (2016), "Supply Chain Management and Construction Project Delivery: Constraints to its Application", Project Management World Journal Volume 5, Issue 5, PP: 1-19

[2] Andrew R. J. Dainty, Geoffrey H. Briscoe and Sarah J. Millett x(2001), "Subcontractor perspectives on supply chain alliances", Construction Management and Economics, ISSN (Print): 0144-6193, ISSN (Online): 1466-433X, PP: 841-848

[3] Baldwin, C.Y., and Clark, K.B., 2000. "Design rules. Volume 1: the power of modularity." MIT, Cambridge MA

[4] DeepeshGiri Sharma, G K Sahu, "Quality in Supply Chain: Case Study of Indian Cement Industry", International Proceedings of Economics Development and Research (IPEDR) 2014, V75. 28

[5] Elizabeth Ojo, Charles Mbowa and Esther T. Akinlabi (2014), "Barriers in Implementing Green Supply Chain Management in Construction industry", International Conference on Industrial Engineering and Operations Management Bali, Indonesia, January 7 - 9, 2014, PP: 1974-1981

[6] Hans Voordijk and Ruben Vrijhoef (2003), "Improving Supply Chain Management in Construction: What Can Be Learned From the Aerospace Industry?" In: Greenwood, D J (Ed.), 19th Annual ARCOM Conference, 3-5 September 2003, and University of Brighton. Association of Researchers in Construction Management, Volume 2, PP: 837-846

[7] Kamal M. Al-Subhi Al-Harbi (1999), "Application of the AHP in project management", International Journal of Project Management 19 (2001), PP: 19-27

[8] Malik Khalfan, Peter McDermott and Rachel Cooper (2004), "Integrating The Supply Chain Within Construction Industry", 20th Annual ARCOM Conference 1-3 September 2004, Heriot Watt University. Association of Researchers in Construction Management, Vol. 2, PP: 897-904.

[9] Mansour N. Jadid and Mobin M. Idrees (2013), “A Geographic Interactive Supply Chain Management System for Construction Projects", World Congress on Engineering and Computer Science (WCECS) 2013, San Francisco, USA, ISBN: 978-988-19253-1-2, ISSN: 2078-0958 (Print), ISSN: 2078-0966 (Online), Volume II.

[10] MullaAneesa.I, Dr. A.K.Gupta, Prof. D.B.Desai (2015), "Supply Chain Management: Effective Tool in Construction Industry", International Journal of Novel Research in Engineering and Science (IJNRES), ISSN: 2394-7349, Vol. 2, Issue 1, PP: 35-40

[11] Per Erik Eriksson (2010), "Improving Construction Supply Chain Collaboration and Performance: A Lean Construction Pilot Project", Supply Chain Management: An International Journal, ISSN: 1359-8546, Volume 15 Number 5, PP: 394-403

[12] Prof. Mukesh S. Balwani, Prof. S.A. Hussain, Prof. Aquib Ansari, Prof. NaseeruddinHaris, "Supply Chain Management in Construction" (2015), International Journal on Recent and Innovation Trends in Computing and Communication (IJRITCC), ISSN: 2321-8169, Volume 3, Issue 2, PP: 141-144

[13] Ruben Vrijhoef and Lauri Koskela (1999), "Roles of Supply Chain Management in Construction", University of California, Berkeley, CA, USA, PP: 133-146

[14] Ruben Vrijhoef and Lauri Koskela (2000), "The Four Roles of Supply Chain Management in Construction", European Journal of Purchasing \& Supply Management 6, PP: 169-178

[15] S Vignesh, S Shanmugapriya (2016), “Improvement of Decision Making Process in Construction Supply Chain Management using Analytical Hierarchy Process", International Journal of Emerging Technology and Advanced Engineering (IJETAE), ISSN: 2250-2459, Volume 6, Issue 4, PP: 109-118

[16] Stuart Tennant and Scott Fernie, "Supply Chain Management In Construction: Three Developments in Search of a Theory", PP: 622-633

[17] SyamaKrishnakumar, Linu T. Kuriakose (2016), "Supply Chain Management in Construction Industry", International Journal of Scientific Engineering and Research (IJSER), ISSN (Online): 2347-3878, Volume 4 Issue 3, PP: 48-52

[18] Syed Mahmood Ahmed, Salman Azhar and Irtishad Ahmad (2002), "Supply Chain Management in Construction Scope, Benefits and Barriers", Delhi Business Review, Vol. 3, No. 1

[19] Vijay Kumar Sahu, Richard Victor (2016), "Supply Chain Management to Minimize Total Transportation Cost of Cement Plant", International Journal of Latest Trends in Engineering and Technology (IJLTET), ISSN: 2278-621X, Volume 6, Issue 3, PP: 103-109

[20] Wee, H.M. and Wu, S. (2009), "Lean Supply Chain and Its Effect on Product Cost and Quality: A Case on Ford Motor Company", Supply Chain Management: An International Journal, Vol. 14 No. 5, PP: 335-41. 
AUTHORS' BIOGRAPHY

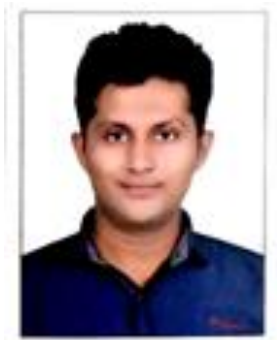

Dhruv Gor, received his bachelor degree in Civil Engineering from the HJD Institute of Technical Education and Research, Kera-Kutch in 2015. At present, he is final year student of Master's Degree in Construction Engineering and Management from Birla Vishvakarma Mahavidyalaya, Gujarat Technological University, Vallabh Vidyanagar, Gujarat, India.

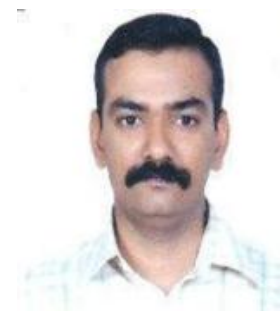

Dr. Jayeshkumar R Pitroda, received his bachelor of engineering degree in Civil Engineering from Birla Vishwakarma Mahavidyalaya Engineering College, Sardar Patel University in 2000. In 2009 he received his master's degree in Construction Engineering and Management from Birla Vishwakarma Mahavidyalaya Sardar Patel University. In 2015 he received his Doctor of philosophy (Ph.D.) degree in Civil Engineering from Sardar Patel University. He joined Birla Vishwakarma Mahavidyalaya Engineering College as a faculty in 2009, where he is Assistant Professor of Civil Engineering Department with a total experience of 17 years in the field of research, designing and education. He is guiding M.E. (Construction Engineering and Management) thesis work in the field of Civil / Construction Engineering. He has published many papers in National / International Conferences and International Journals. He has published seven Research Books in the field of Civil Engineering, Rural Road Construction, National Highways Construction, Utilization of Industrial Waste, Fly Ash Bricks, Construction Engineering and Management, Eco-friendly Construction.

Citation: Dr. Jayeshkumar Pitroda et.al. (2018) A Critical Literature Review of Impact of Supply Chain Management Practice on Construction Project Performance, International Journal of Constructive Research in Civil Engineering, 4(1), pp.14-22. DOI: http://dx.doi. org/10.20431/2454-8693.0401002

Copyright: () 2018 Dr. Jayeshkumar Pitroda, This is an open-access article distributed under the terms of the Creative Commons Attribution License, which permits unrestricted use, distribution, and reproduction in any medium, provided the original author and source are credited. 